OLGA ALICJA MATYSIAK ${ }^{1}$

SWPS Uniwersytet Humanistycznospołeczny

ANETA BRZEZICKA

SWPS Uniwersytet Humanistycznospołeczny
Studia Psychologica UKSW

17(2) 2017 s. $5-21$

DOI:10.21697/sp.2017.17.2.01

\title{
SKUTECZNOŚĆ TRENINGÓW POZNAWCZYCH W GRUPIE OSÓB STARSZYCH - PRZEGLĄD BADAŃ
}

\begin{abstract}
STRESZCZENIE
Na świecie stopniowo wzrasta liczba osób dożywających sędziwego wieku. Jednocześnie wraz z wiekiem ulega pogorszeniu szereg procesów poznawczych, takich jak: pamięć, uwaga, szybkość przetwarzania informacji czy kontrola poznawcza. Z tego względu bardzo popularne stały się programy usprawniające zdolności intelektualne tej grupy. Jednym z szeroko dyskutowanych podejść jest wspomaganie funkcjonowania osób starszych z wykorzystaniem treningów poznawczych. Powstałe reżimy treningowe są przez część badaczy uznawane za skuteczne, przez innych zaś systematycznie krytykowane. Obserwujemy heterogeniczność podejść zarówno do samego treningu, jak i do metodologii badań. Z punktu widzenia ich użyteczności kluczowe jest natomiast rozstrzygnięcie, jakiego rodzaju interwencje są najbardziej skuteczne, jak szeroki mają zasięg i w jakim stopniu przekładają się na realne korzyści dla trenujących. Profitem powinna być przede wszystkim poprawa jakości codziennego życia. Dlatego niniejszy artykuł ma na celu nie tylko systematyzację doniesień z dziedziny usprawniania funkcjonowania poznawczego osób starszych, lecz przede wszystkim zwrócenie uwagi na coraz bardziej odczuwalny problem weryfikacji efektywności treningów poznawczych seniorów. Pragniemy podkreślić potrzebę wprowadzenia silniejszej unifikacji metodologicznej interwencji poznawczych w celu umożliwienia rzetelnej oceny ich wpływu na jakość życia badanych seniorów. Na podstawie dokonanego przeglądu przedstawiamy sugestie dotyczące metodologii treningów.
\end{abstract}

Słowa kluczowe: starzenie się, procesy poznawcze, treningi poznawcze, transfer zdolności, zdrowi seniorzy

Adres do korespondencji: omatysiak@st.swps.edu.pl. Praca została sfinansowana ze środków Narodowego Centrum Nauki przyznanych na podstawie decyzji NCN nr 2014/13/B/ HS6/03155. 


\title{
THE EFFECIVENESS OF COGNITIVE TRAININGS IN OLDER ADULTS - REVIEW
}

\begin{abstract}
There is a gradual increase in the number of elderly people living in the world. Also, human aging is associated with a deterioration of cognitive processes, that touches multiple domains, including memory, attention, processing speed and cognitive control. For this reason, intervention programs that improve the intellectual functioning of older citizens became very popular. One of the broadly discussed approach aims to support the elderly's functioning with the usage of cognitive trainings. Although, emerged training regimes are considered by some researchers to be effective, they are systematically criticized by others. Possible causes are due to a diversity of approaches to the training design itself, to the way it is applied, as well as to the training methodology. In terms of their utility, it is crucial to decide which interventions are effective, how strongly they affect behavior, and to what extent they actually transfer to everyday life of older participants. Especially the last attribute should be essential, considering participants' well-being. Therefore, this article aims not only to systematize reports on improving the cognitive functioning of the elderly, but above all to draw attention to the increasingly perceptible problem of verification of the training effects of seniors. We would like to emphasize the need for implementation a stronger methodological unification of cognitive trainings, that allows a fair assessment of their impact on the quality of life of the participating seniors.
\end{abstract}

Keywords: aging, cognitive functioning, cognitive trainings, transfer of training, healthy older adults

W Polsce stopniowo wzrasta liczba mieszkańców, którzy ukończyli 60 lat. Zgodnie z prognozą GUS-u na 2050 rok, w naszym kraju będzie żyło blisko $10 \mathrm{mln}$ Polaków w wieku emerytalnym. A już za 15 lat co czwarty Polak przekroczy 80. rok życia (Rocznik Statystyczny, 2014). Jednocześnie nawet zdrowemu starzeniu nieodłącznie towarzyszy stopniowe pogarszanie się funkcjonowania poznawczego (Salthouse, 2006). Zmiany obserwuje się w wypełnianiu zadań wymagających podzielności uwagi, jej wybiórczości oraz podtrzymywania (np. Quigley, Muller, 2014; Zec, 1995). Również funkcje wykonawcze osłabiają się z wiekiem (Fisk, Sharp, 2004). Obserwujemy zaburzenia kontroli poznawczej oraz spadek wydajności mechanizmów hamujących (West, Bowry, 2005). Jednak najczęściej sygnalizowanym przez seniorów problemem jest gorsza pamięć. Udowodniono (np. Park, Festini, 2016), że znaczne różnice związane z wiekiem występują w obrębie pamięci deklaratywnej oraz pamięci epizodycznej (episodic memory - EM), chociaż pamięć proceduralna jest w stosunkowo dobrej kondycji (Nyberg, Lövdén, Riklund, Lindenberger, Bäckman, 2012). Jednakże z czasem osłabia się przede wszystkim funkcjonowanie pamięci operacyjnej (working memory - WM; McNab i in., 2015), z czym związana jest także deterioracja pamięci prospektywnej (Altgassen, Kliegel, Brandimonte, Filippello, 2010). 
Wszystkie te zmiany powodują spadek jakości życia seniorów. A skoro, jak słusznie zauważył de Lesseps, Być starym to jedyny sposób, by żyć długo, nie pozostaje nam nic innego, jak stawić im czoła. Naukowcy, działacze polityczni oraz komercyjni przedsiębiorcy starają się stworzyć programy interwencji prowadzących do polepszenia sprawności intelektualnej osób w podeszłym wieku. Powstałe w wyniku setek badań treningi poznawcze są przez niektórych uznawane za skuteczne (np.: Kueider, Parisi, Gross, Rebok i in., 2014; Lustig, Shah, Seidler, Reuter-Lorenz, 2009; Morrison, Chein, 2011; Reijnders, van Heugten, van Boxtel, 2013), inni jednak sądzą, że nie ma przekonujących dowodów, aby inwestować czas i środki w tego typu interwencje (np. Owen i in., 2010).

Niniejszy artykuł ma na celu nie tylko systematyzację doniesień z dziedziny usprawniania funkcjonowania poznawczego osób starszych, lecz także zwrócenie uwagi na coraz bardziej zauważalny problem weryfikacji efektów treningów w grupie seniorów. Zebrane prace przedstawiamy ze szczególnym podkreśleniem rozbieżności między nimi. Pragniemy zwrócić uwagę na potrzebę wprowadzenia silniejszej unifikacji metodologicznej treningów w celu umożliwienia rzetelnej oceny ich wpływu na jakość życia badanych seniorów.

\section{RODZAJE I MIARY SKUTECZNOŚCI TRENINGóW POZNAWCZYCH}

Systematyka treningów zdolności poznawczych oferowanych osobom starszym jest oparta przede wszystkim na następujących kryteriach: 1) jaki mechanizm leży u podstaw treningu; 2) na jak wiele domen jest on ukierunkowany; 3) w jaki sposób jest przeprowadzany; 4) ile osób uczestniczy w wykonywaniu zadania. Charakterystyka tych interwencji została przedstawiona w tabeli 1 .

Ocena skuteczności treningów jest rozpatrywana w czterech kategoriach. Są to:

1. Bezpośrednia poprawa $\mathrm{w}$ zadaniu trenowanym;

2. Przeniesienie efektów treningowych do innych zadań kryterialnych transfer. Powszechnie wyróżnia się jego dwa główne typy: bliski i daleki (Lacker, 1990). Transfer bliski obserwujemy podczas przeniesienia efektów do zadań nietrenowanych, ale bazujących na tym samym procesie czy ćwiczonej modalności. Transfer daleki zachodzi, gdy przeprowadzona interwencja wpływa na wyniki w testach angażujących odrębne funkcje poznawcze (Morrison, Chein, 2011). Kluczowy jest zatem rodzaj testów kryterialnych zastosowanych do weryfikacji transferu;

3. Utrzymywanie się efektów treningowych. Kontrola następuje przez przeprowadzenie tzw. sesji odroczonej (follow up), odbywanej po kilkukilkunastu tygodniach. Realizowane są niekiedy projekty badawcze sprawdzające efekty po dwóch czy nawet 10 latach, stanowią one jednak pojedyncze przypadki (kolejno: Ball i in., 2002; Rebok i in., 2014); 


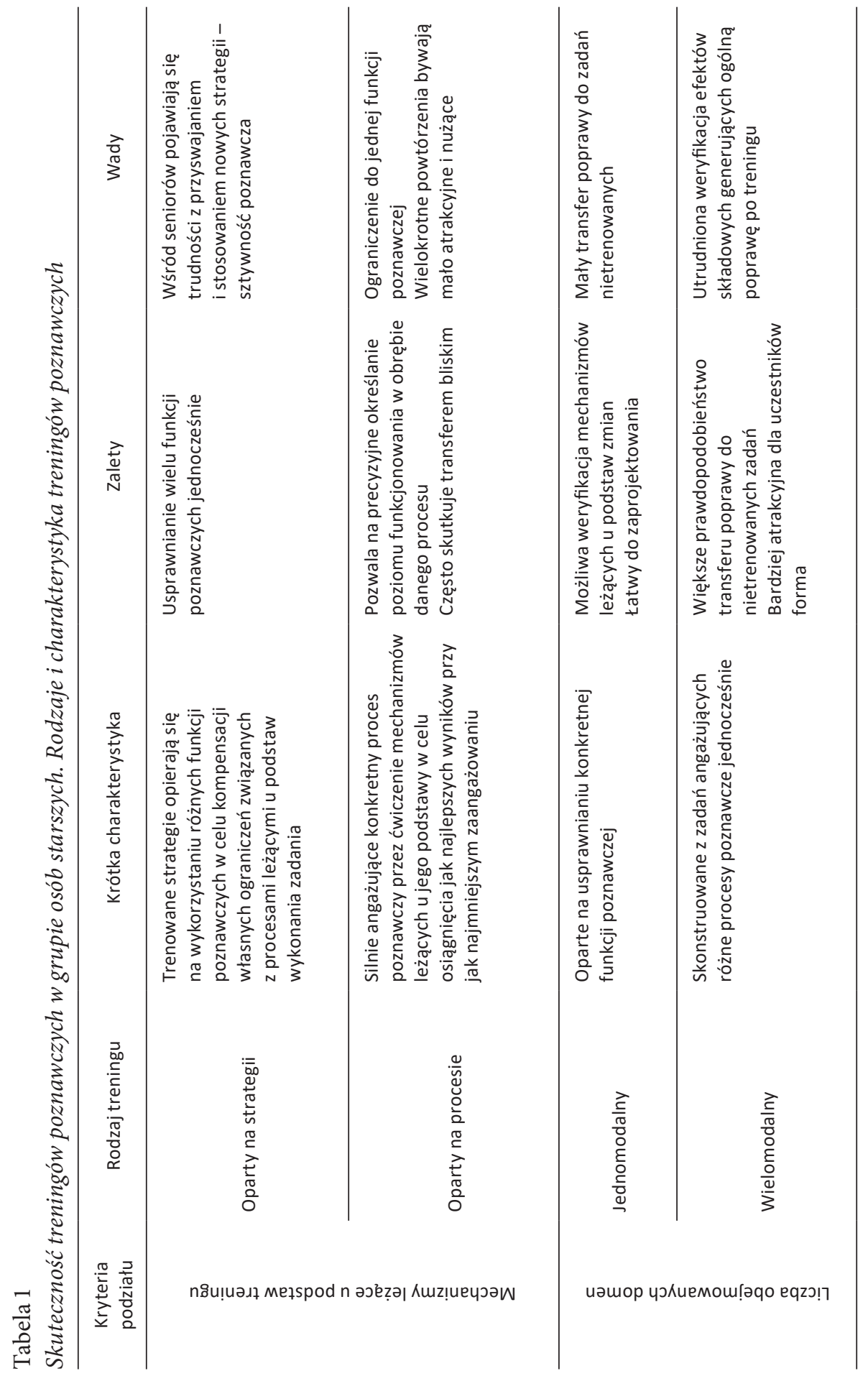




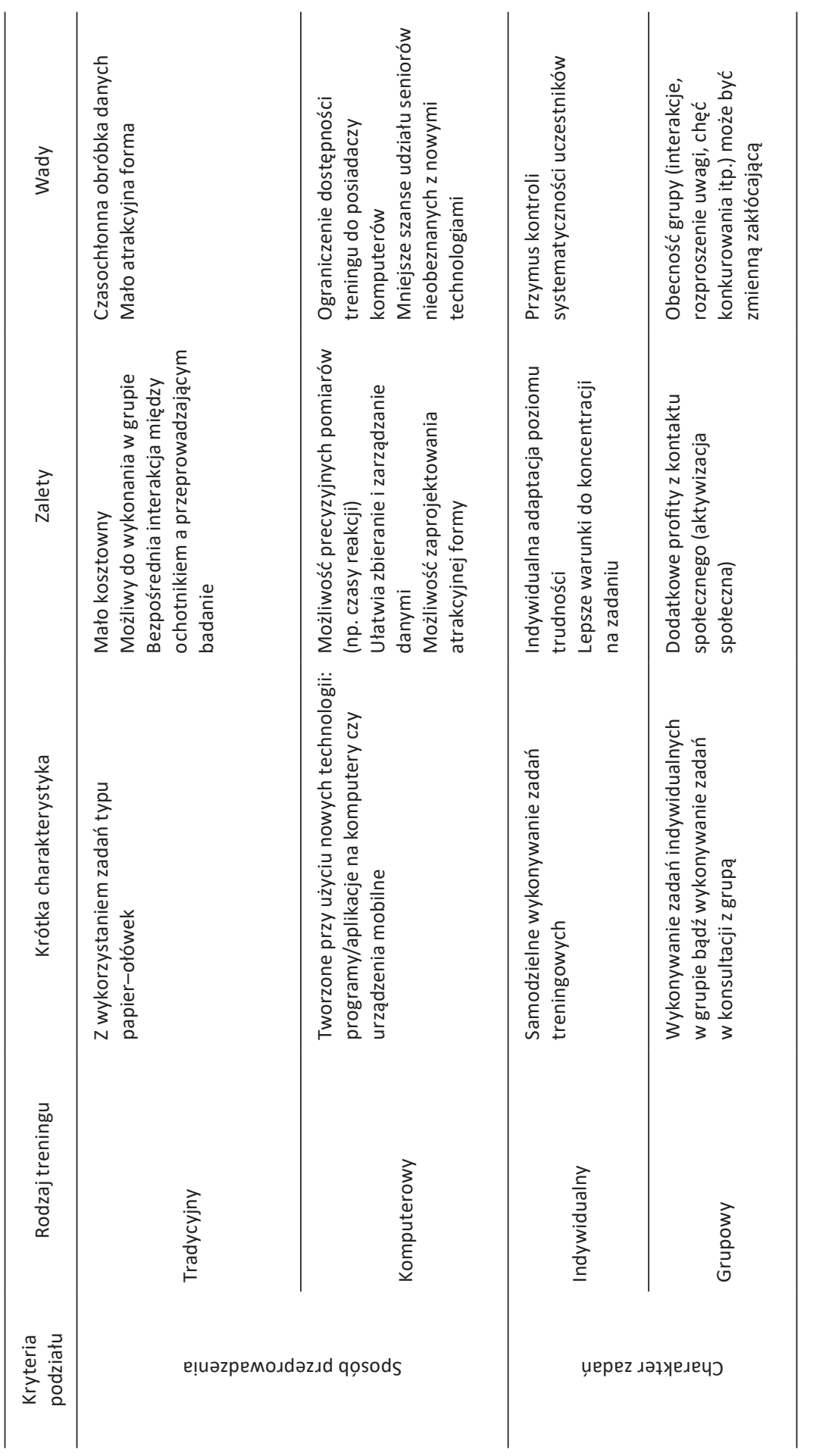


4. Generalizacja wyników. To ocena przeniesienia efektów treningu do codziennego funkcjonowania. Wskaźnik ten jest uznawany za trudny do weryfikacji w warunkach laboratoryjnych, przez co jest uwzględniany stosunkowo rzadko.

\section{OMóWIENIE METAANALIZ I PRAC PRZEGLĄDOWYCH}

W 2009 r. Papp, Walsh i Snyder pisali o niewielkiej ilości literatury naukowej eksplorującej wpływ treningów poznawczych na zdrowo starzejące się jednostki. Jednak przez ostatnie 10 lat (do 2016 r.) opublikowano 16 anglojęzycznych przeglądów i metaanaliz badań mających na celu uporządkowanie danych $\mathrm{z}$ tego zakresu i zebranie płynących z nich wniosków.

\section{Treningi strategiczne vs oparte na procesie}

Przegląd Lustig i in. (2009) potwierdził skuteczność treningów strategicznych na przykładzie transferu bliskiego efektów treningów pamięci. Także Reijnders $\mathrm{i}$ in. (2013) opisali istotne poprawy zarówno w ćwiczonym zadaniu, jak i w podobnych testach po treningach strategicznych funkcji wykonawczych (executive functions - EF), uwagi czy szybkości percepcyjnej (perceptual speed - PS). Nie było podstaw, aby mówić o generalizacji tych popraw, choć subiektywna ocena funkcjonowania uczestników po treningu wzrosła. Podobną obserwację poczyniły Jak, Seelye i Jurick (2013). Opierając się na pracach raportujących transfer daleki w treningach pamięci, Zelinski (2009) wysunęła hipotezę, iż osoby starsze (jako uczestnicy o wyjściowo niższych zasobach poznawczych) mają skłonność do niekorzystania z promowanej strategii i powracania do technik wyuczonych wcześniej (Hertzog, Touron, Hines, 2007).

Treningów opartych na procesie problem ten nie dotyczy, mają więc one większy potencjał do transferu dalekiego. Na przykład Kelly i współpracownicy (2014) wykazali poprawę wyników w testach, niezależną od charakteru grupy kontrolnej (bierna / aktywna). I choć były to głównie postępy w zadaniach podobnych ( $\mathrm{w} 21 \mathrm{z} 31$ randomized controlled trial - RCT), to siedem publikacji donosiło o transferze dalekim (m.in. Ball i in., 2002; Carretti, Borella, Fostinelli, Zavagnin, 2012; Mozolic, Hayasaka, Laurienti, 2011), a badani raportowali wzrost subiektywnego poziomu funkcjonowania poznawczego. Każda z 14 interwencji opisanych przez Tardif i Simard (2011; dziewięć było opartymi na procesie treningami pamięci) także skutkowała transferem do przynajmniej jednego nietrenowanego zadania.

\section{Treningi wielomodalne i jednomodalne}

Lustig i in. (2009) dowiodły, że wielomodalne wersje treningów opartych na procesie wpływają pozytywnie na pomiary posttreningowe. Efekt był widoczny w zadaniach pokrewnych ( $d=0,73$; Dunlosky, Kubat-Silman, Hertzog, 2003), 
podczas wykonywania codziennych zadań angażujących pamięć oraz w sferze subiektywnych odczuć osób badanych (Rebok, Carlson, Langbaum, 2007). Przegląd aż 402 raportów badawczych (z których jedynie 35 badań pamięci spełniło kryteria włączenia do metaanalizy!) potwierdził wystąpienie transferu po wszystkich treningach, jednak bazujące na procesie treningi wielomodalne skutkowały istotnie większymi poprawami pamięci niż strategiczne (Gross i in., 2012). W serii projektów (np. Craik i in., 2007; Stuss i in., 2007) wykazano natomiast, że interwencja psychologiczna łączona z treningami strategicznymi przyczyniła się do poprawy wyników zadań symulujących problemy życia codziennego. Wpłynęła też pozytywnie na subiektywne odczucie sprawczości badanych oraz na ich dobre samopoczucie. Projekt COGITO Study przyniósł podobne efekty. Skuteczność tego 100-dniowego treningu PS, EM oraz WM była sprawdzana w obrębie PS, EM, WM oraz rozumowania. Łączona interwencja skutkowała bezpośrednią poprawą wyników w testach i transferem do funkcji poznawczych reprezentowanych przez czynniki latentne (Schmiedek, Lövdén, Lindenberger, 2010). Dowody na generalizację wielomodalnych posttreningowych popraw dostarczyło również ACTIVE Study (Rebok, 2007). Treningi pamięci, PS oraz rozumowania przyniosły transfer do codziennego funkcjonowania, mierzony na kilku skalach, np. Instrumental Activities of Daily Living, Everyday Problems Test, Observed Tasks of Daily Living. Efekt utrzymał się minimum pięć lat (Willis i in., 2006). Ponadto w grupie trenującej odnotowano 33-procentową redukcję ryzyka rozwoju zaburzeń poznawczych i demencji. U osób, które odbyły sesje wprowadzające (booster sessions), szansa ta wzrosła aż do 48\%. Także według Mowszowski, Lampita, Waltona i Naismith (2016) połowa z opracowanych raportów świadczyła o utrzymaniu się efektów (po miesiącu: Dawson i in., 2014; po roku: Cheng i in., 2012), co sugeruje, że generalizacja zysków treningowych może się manifestować dopiero po upływie czasu.

Taka synkretyczna interwencja może przezwyciężyć ograniczenia związane z pojedynczym treningiem. Należy jednak zachować ostrożność. Autorzy przeglądu treningów WM (Cândea, Cotet, Stefan, Valenas, Szentagotai-Tatar, 2015) wykazali, że jednoczesne trenowanie kilku funkcji poznawczych w jednej sesji treningowej skutkuje poprawą mniejszą, niż kiedy dana domena jest trenowana osobno. I choć zaobserwowany rezultat może być specyficzny dla WM, to możliwe jest, że im więcej obszarów ćwiczymy jednocześnie, tym stosunkowo mniej czasu jest poświęcane każdemu z nich. Niewykluczone zatem, że dla programów wielomodalnych liczba i czas sesji powinny być odpowiednio większe.

Duża część z opisanych powyżej prac obejmuje analizę efektywności treningów jednej domeny poznawczej, głównie pamięci (np.: Cândea i in., 2015; Kelly i in., 2014; Martin, Clare, Altgassen, Cameron, Zehnder, 2011; Rebok i in., 2014; Tardif, Simard, 2011). Martin i współpracownicy (2011) wykazali, że spośród publikacji z lat 1970-2007 jedynie ten rodzaj badań spełniał kryteria włączenia do metaanalizy. Raport głosił, że po treningu pamięci badani poprawili swoje 
wyniki w testach pamięci, jakkolwiek nie były to poprawy większe niż w grupie kontrolnej. Odwrotnie wykazali Papp i in. (2009). Obliczony wskaźnik transferu (bliskiego) dla osób po treningu był wyższy niż w grupach kontrolnych, niezależnie od ich rodzaju (przy grupie aktywnej $d=0,17$; z grupą pasywną $d=0,18$ ). Także Gross i in. (2012) zaraportowali różnicę między pomiarami przed treningiem i po nim równą $0,43 S D$ oraz między poprawami trenujących a kontrolą wynoszącą $0,31 S D$.

Eksploracja wyników treningów uwagi oraz EF nie dała jednoznacznych odpowiedzi na temat ich skuteczności. W przeglądzie Reijnders i in. (2013) odnotowano transfer w dwóch badaniach treningów uwagi oraz w pięciu z ośmiu interwencji opartych na funkcjach poznawczych. W opracowaniu Kelly i in. (2014) poprawy pojawiły się po siedmiu z 16 interwencji EF. Metaanaliza Lampita, Hallocka i Valenzueli (2014) wykazała, że treningi EF i uwagi nie zaowocowały istotnymi poprawami. Jednak w kolejnej publikacji ten sam zespół zaraportował istnienie transferu bliskiego po interwencji EF (Mowszowski i in., 2016).

I choć znane są teorie głoszące, że treningi zdolności metapoznawczych mają większe szanse na generalizację efektów widoczną w zadaniach nietrenowanych (np. Reijnders i in., 2013), to również ich analizy nie są jednoznaczne. Tardif i Simard (2011) w omówieniu zebranych przez siebie prac powtarzają za ich autorami, iż brak homogeniczności rezultatów może wynikać z zastosowania różnych testów kryterialnych do pomiaru tych samych funkcji (zob. też: Jak, Seelye, Jurick, 2013).

Dużo mniej wątpliwości wzbudza skuteczność treningów PS. Praca O'Connor, Hudak i Edwards (2011) potwierdza, że zastosowanie dobrze dobranych zadań kryterialnych w treningach opartych na procesie przekłada się na raportowanie bardziej rzetelnych wyników. Zwięzły przegląd wykazał, że tego rodzaju ingerencja usprawnia wykonanie zadania useful field of view test (UFOV). UFOV jest powszechnie uznawanym predyktorem mobilności osób starszych, która pozytywnie koreluje z jakością życia seniorów (Wood, Owsley, 2016). Także pozostałe prace analizujące wpływ treningów PS raportują ich bezsporną skuteczność (np. Kueider i in., 2012; Tardif, Simard, 2011).

\section{Treningi grupowe vs indywidualne}

Znaczenie dla efektywności interwencji wydaje się mieć także sama forma administrowania treningu. Kelly i współpracownicy (2014) dowiedli, że osoby trenujące wspólnie wypadły w testach pamięci o 50\% lepiej niż ochotnicy ćwiczący indywidualnie. Co więcej, raportowały też istotnie wyższe poczucie sprawczości i mniejsze obawy dotyczące funkcjonowania swojej pamięci. Również metaanaliza (Lampit i in., 2014) potwierdza moderujący i pozytywny wpływ czynnika przynależności do grupy na progres treningowy. 


\section{Treningi komputerowe vs klasyczne}

Udowodniono, że siła transferu w zadaniach komputerowych jest większa niż raportowana w podejściach klasycznych, a seniorzy nie potrzebują wcześniejszego doświadczenia w pracy z komputerem, aby czerpać korzyści z treningu (Kueider i in., 2012). Dodatkowo bogatsza forma prezentacji materiału bardziej angażuje uczestnika, co wśród osób starszych pozytywnie koreluje z osiąganymi wynikami (np. West, Bagwell, Dark-Freudeman, 2008).

\section{NiEdostATKI TRENINGóW POZNAWCZYCH SENIORÓW}

Sukces i rozgłos programów treningowych zwróciły uwagę nie tylko ich entuzjastów, lecz także i sceptyków. W 2010 r. niemal 11,5 tys. dorosłych i seniorów, przez sześć tygodni (min. $10 \mathrm{~min}$, co najmniej trzy razy w tygodniu), ćwiczyło on-line: pamięć, planowanie, zdolności przestrzenne i uwagę lub rozumowanie, planowanie i rozwiązywanie problemów. Chociaż uczestnicy poczynili istotne postępy w trenowanych zadaniach oraz pokrewnych testach $(d=0,73$ do $d=1,63)$, to transfer daleki był znikomy $(d=0,01$ do $d=0,35)$. Autor podsumował doświadczenie, pisząc o „powszechnym przecenianiu efektów komputerowych treningów mózgu" (Owen i in., 2010). Publikacja, choć szybko zdeprecjonowana (np. Zelinski, 2010), przyczyniła się do częstszego prezentowania krytycznych stanowisk wobec treningów poznawczych, w tym ćwiczeń seniorów.

Buitenweg, Murre i Ridderinkhof (2012) postulowali, że często obserwowane stosowanie nieadaptacyjnych zadań treningowych, a także nieregularne pojawianie się w nich nowych elementów jest przyczyną rzadkiej generalizacji popraw. Tymczasem rosnące wymagania zmuszają uczestników do ciągłego utrzymywania stanu gotowości i stwarzają potencjał do transferu dalekiego. Indywidualnie dopasowany poziom trudności działa pozytywnie na poczucie sprawczości i satysfakcję osób starszych, które są szczególnie wrażliwe na negatywne bodźce związane z wykonaniem zadania (Kueider i in., 2012). Jednocześnie włączenie elementów „nowości” owocuje tworzeniem nowych połączeń neuronalnych, dzięki czemu zwiększa wydajność poznawczą trenujących.

Lampit i in. (2014) wykazali, że sesje treningowe krótsze niż 30 min były nieskuteczne. Również trenowanie częściej niż trzy razy w tygodniu nie przyniosło większej poprawy, a nawet zneutralizowało wcześniejsze pozytywne efekty. Przyczyną może być zmęczenie poznawcze towarzyszące zbyt częstym bądź zbyt intensywnym stymulacjom (Holtzer i in., 2011). Martin i in. (2011) postulują natomiast, aby zwiększać całkowity czas trwania interwencji (w tym liczbę sesji treningowych), ze względu na trudność zaobserwowania popraw funkcjonowania poznawczego $\mathrm{w}$ tak krótkim okresie, w jakim zazwyczaj jest administrowany trening. Jednocześnie badań trwających dłużej niż pół roku opublikowano zbyt mało, aby można je było uwzględniać w metaanalizach. 
Co więcej, zaskakująco niewielka liczba badań w ogóle spełnia kryteria włączenia - jedynie 24 interwencje $z$ okresu 37 lat.

Lampit i in. (2014) dowiedli też, że pozytywne efekty treningowe są widoczne jedynie w porównaniu z nieaktywną grupą kontrolną. Obserwację potwierdzili Reijnders i in. (2013) oraz Tardif i Simard (2011). Chociaż w pozostałych przytaczanych tu pracach odnotowano istotnie wyższe poprawy w grupach treningowych. Uwidacznia to problem wpływu zastosowanego w projekcie rodzaju grupy kontrolnej na wielkość i jakość uzyskanych wyników.

Zauważalne jest również, iż niepokojąco małą liczbę publikacji zaprojektowano tak, aby można było oszacować utrzymywanie się efektów treningowych. Mimo wszystko Kelly i współpracownicy (2014) oszacowali, że szanse na wystąpienie długofalowych efektów treningowych wzrastają dzięki zastosowaniu: booster sessions, paradygmatów adaptacyjnych, co najmniej 10 sesji treningowych oraz trenowaniu w grupach lub pod opieką trenera.

Zarzuty dotyczą także doboru zadań kryterialnych służących do pomiaru przed treningiem i po nim. Dobrym przykładem są cytowane już prace zespołu z Sydney (Lampit, Hallock, Valenzuela, 2014; Mowszowski i in., 2016). Według ich autorów przyczyną sprzecznych rezultatów dotyczących skuteczności treningów EF był albo efekt ekspozycji pojawiający się w pomiarach posttreningowych, albo niejednorodne dobieranie grupy kontrolnej. Co więcej, w analizowanych badaniach wystąpiło zróżnicowanie nie tylko rodzaju kontroli dla treningu, lecz także testów kryterialnych, a nawet wskaźników i miar stosowanych w obrębie tych samych zadań. W pierwszej pracy ogromna różnorodność i niska jakość metodologiczna opublikowanych strategicznych treningów EF (znów ponad połowa z 13 opisywanych RCT wypadała poniżej średniej na skali jakości metodologicznej PEDro) stanowiły wręcz barierę dla integracji zawartych w nich informacji i uniemożliwiły dokonanie ich metaanalizy. Tej samej frustracji stawiali czoła Reijnders i in. (2013).

Jednak największy wpływ na uzyskane wyniki zdaje się mieć metoda analizy danych. Przykładowo, badania uwzględniające porównania między osobami (between-subject) zazwyczaj raportują niewielki transfer bliski i niemal zerowy transfer daleki. Ale jeśli dokonywana jest analiza wewnątrzosobowa (within-subject; niestety wykonuje się ją rzadko), to poprawy są rozleglejsze (np. Belleville i in., 2006; Engvig i in., 2010). Co więcej, badacze raportowali czasem pre- i posttreningowe średnie oraz odchylenia standardowe, a niekiedy standaryzowali dane w odniesieniu do wyników grupy kontrolnej. W niektórych publikacjach obliczano wielkość efektu (uwzględniając przedziały ufności lub nie), w innych prezentowano wyniki jako różnicę między pomiarami. Pojawiało się nawet modelowanie strukturalne z użyciem zmiennych latentnych. 


\section{Podsumowanie}

Przywołane wyniki pozwalają na wyciągnięcie optymistycznych, jakkolwiek ostrożnych wniosków. Efekty treningów poznawczych są pozytywne, raczej specyficzne i rzadko owocują poprawą ogólnej sprawności intelektualnej.

W grupie seniorów zadania oparte na procesie wydają się bardziej efektywne niż techniki strategiczne. Jednak gdy interwencja ma charakter wielomodalny, zdecydowanie większe znaczenie ma kompleksowość działań. Treningi procesów zdają się mieć większy potencjał do generalizacji popraw i ich utrzymywania się po zakończeniu projektu. Treningi wielomodalne stosunkowo często przynoszą widoczne efekty w obrębie ogólnej sprawności intelektualnej trenujących. Trzeba jednak pamiętać, że tego rodzaju programy w ogóle częściej zawierają testy mierzące tę zmienną. Tymczasem ćwiczenia oparte na pojedynczej domenie niemal zawsze przynoszą pozytywne efekty w obrębie ćwiczonej zdolności, ale relatywnie rzadko owocują transferem dalekim. Zależność tę obrazują m.in. efekty treningów pamięci. Wyniki interwencji dotyczących pozostałych domen nie są rozstrzygające. Wyjątkiem jest trening PS. W każdym opisywanym badaniu zaowocował on poprawami w zadaniach podobnych i usprawnił ogólne funkcjonowanie trenujących. Weryfikacja teorii, że treningi zdolności metapoznawczych z większym prawdopodobieństwem oddziałują na ogólną sprawność intelektualną, również nie jest jednoznaczna.

Nie budzi wątpliwości twierdzenie, że siła transferu w zadaniach komputerowych jest większa niż w podejściach klasycznych, a seniorzy nie potrzebują doświadczenia w pracy z komputerem, aby czerpać korzyści z treningu. Także trening w grupie zdaje się oddziaływać na uzyskiwane poprawy posttreningowe bardziej pozytywnie. Warto zwrócić uwagę na fakt, iż niezależnie od miar obiektywnych sami uczestnicy mają tendencję do raportowania subiektywnie odczuwanych pozytywnych zmian w swoim ogólnym funkcjonowaniu poznawczym.

Pragniemy podkreślić jednak, że każda próba podsumowania opublikowanych dotychczas wyników jest obarczona błędami. Heterogeniczność metodologiczna stanowi bolączkę właściwie każdego cytowanego opracowania. Błędy bywają tak podstawowe jak badanie nierównolicznych grup, niewłączanie grup kontrolnych albo włączanie grup kontrolnych różnego rodzaju. Co więcej, badacze stosują odmienne procedury i paradygmaty badawcze w celu weryfikacji tych samych hipotez. Powszechne są aberracje związane ze stosowaniem różnej liczby sesji badawczych o różnym czasie trwania, niejednolitych przerw między spotkaniami treningowymi czy okresów odroczenia sesji follow up. Nie możemy także zapomnieć o opracowywaniu przez badaczy różnorakich adaptacji tych samych zadań oraz o powszechnym wykorzystywaniu odmiennych miar i testów do weryfikowania skuteczności takich samych treningów, jak również o znaczeniu wyboru metody opracowania i analizy zebranych danych (np. Martin i in., 2011; Papp i in., 2009). 
Co zatem zrobić, aby wnioskowanie o skuteczności treningów poznawczych seniorów mogło przebiegać na bardziej „globalnym” poziomie? Wnioskując na podstawie przytoczonych prac, proponujemy:

- Użycie komputerowej wersji treningu o adaptacyjnym poziomie trudności

- Przeprowadzenie min. 10 sesji treningowych o czasie dopasowanym do liczby zadań

- Włączenie sesji wprowadzających (booster sessions)

- Stosowanie pozytywnego feedbacku, informującego o postępie w wykonywaniu zadania

- Organizację zajęć w grupach

- Przeprowadzenie przynajmniej jednej sesji odroczonej (follow up)

- Solidne osadzenie stosowanych zadań kryterialnych w literaturze teoretycznej

- Włączenie testów weryfikujących ogólny poziom funkcjonowania poznawczego.

Szczęśliwie coraz więcej tych elementów pojawia się w prowadzonych projektach. Rozpowszechnianie informacji o tworzeniu spójnych i globalnie weryfikowalnych projektów badawczych przestaje być kwestią pomijaną w środowisku twórców badań treningowych. Pozwala nam to optymistycznie patrzeć w przyszłość badań nad treningami poznawczymi osób starszych.

\section{Bibliogr AFIA}

Altgassen, M., Kliegel, M., Brandimonte, M., Filippello, P. (2010). Are older adults more social than younger adults? Social importance increases older adults' prospective memory performance. Aging, Neuropsychology, and Cognition, 17, 312-328. DOI:10.1080/13825580903281308

Ball, K., Berch, D. B., Helmers, K. F., Jobe, J. B., Leveck, M. D., Marsiske, M., ... Willis, S. L. (2002). Effects of cognitive training interventions with older adults: A randomized controlled trial. JAMA: The Journal of the American Medical Association, 288, 2271-2281. DOI:10.1001/jama.288.18.2271

Belleville, S., Gilbert, B., Fontaine, F., Gagnon, L., Ménard, É., Gauthier, S. (2006). Improvement of episodic memory in persons with mild cognitive impairment and healthy older adults: Evidence from a cognitive intervention program. Dementia and Geriatric Cognitive Disorders, 22, 486-499. DOI:10.1159/000096316

Buitenweg, J., Murre, J., Ridderinkhof, K. (2012). Brain training in progress: A review of trainability in healthy seniors. Frontiers in Human Neuroscience, 6, 183. DOI:10.3389/fnhum.2012.00183

Byczewska, K., Kielar-Turska, M. (2011), Funkcje zarządzające u osób w wieku senioralnym o różnym poziomie potrzeb edukacyjnych. Psychologia Rozwojowa, 16(1), 85-98. 
Carretti, B., Borella, E., Fostinelli, S., Zavagnin, M. (2012). Benefits of training working memory in amnestic mild cognitive impairment: Specific and transfer effects. International Psychogeriatrics, 25, 617-626. DOI:10.1017/ S1041610212002177

Cândea, D. M., Cotet, C. D., Stefan, S., Valenas, S. P., Szentagotai-Tatar, A. (2015). Computerized cognitive training for working memory in older adults: A review. Transylvanian Journal of Psychology, 16, 141-161.

Cheng, Y., Wu, W., Feng, W., Wang, J., Chen, Y., Shen, Y., ... Li, C. (2012). The effects of multi-domain versus single-domain cognitive training in non-demented older people: A randomized controlled trial. BMC Medicine, 10, 30. DOI:10.1186/1741-7015-10-30

Craik, F. I., Winocur, G., Palmer, H., Binns, M. A., Edwards, M., Bridges, ... Stuss, D. T. (2006). Cognitive rehabilitation in the elderly: Effects on memory. Journal of the International Neuropsychological Society, 13, 132-142. DOI:10.1017/S1355617707070166

Dawson, D., Richardson, J., Troyer, A., Binns, M., Clark, A., Polatajko, H., ... Bar, Y. (2014). An occupation-based strategy training approach to managing age-related executive changes: A pilot randomized controlled trial. Clinical Rehabilitation, 28, 118-127. DOI:10.1177/0269215513492541

Dunlosky, J., Kubat-Silman, A., Hertzog, C. (2003). Training monitoring skills improves older adults' self-paced associative learning. Psychology and Aging, 18, 340-345. DOI:10.1037/0882-7974.18.2.340

Engvig, A., Fjell, A., Westlye, L., Moberget, T., Sundseth, Ø., Larsen, V., Walhovd, K. (2010). Effects of memory training on cortical thickness in the elderly. Neuroimage, 52, 1667-1676. DOI:10.1016/j.neuroimage.2010.05.041

Fisk, J., Sharp, C. (2004). Age-related impairment in executive functioning: Updating, inhibition, shifting, and access. Journal of Clinical and Experimental Neuropsychology, 26(7), 874-890. DOI:10.1080/13803390490510680

Gross, A., Parisi, J., Spira, A., Kueider, A., Ko, J., Saczynski, J., ... Rebok, G. (2012). Memory training interventions for older adults: A meta-analysis. Aging \& Mental Health, 16, 722-734. DOI:10.1080/13607863.2012.667783

Hertzog, C., Touron, D., Hines, J. (2007). Does a time-monitoring deficit influence older adults' delayed retrieval shift during skill acquisition? Psychology and Aging, 22, 607-624. DOI:10.1037/0882-7974.22.3.607

Holtzer, R., Mahoney, J. R., Izzetoglu, M., Izzetoglu, K., Onaral, B., Verghese, J. (2011). fNIRS study of walking and walking while talking in young and old individuals. The Journals of Gerontology. Series A: Biological Sciences and Medical Sciences, 66, 879-887. DOI:10.1093/gerona/glr068

Hussey, E., Novick, J. (2012). The benefits of executive control training and the implications for language processing. Frontiers in Psychology, 3, 1-14. DOI:10.3389/fpsyg.2012.00158 
Jak, A., Seelye, A., Jurick, S. (2013). Crosswords to computers: A critical review of popular approaches to cognitive enhancement. Neuropsychology Review, 23, 13-26. DOI:10.1007/s11065-013-9226-5

Jobe, J. B., Smith, D. M., Ball, K., Tennstedt, S. L., Marsiske, M., Willis, S. L., ... Kleinman, K. (2001). ACTIVE: A cognitive intervention trial to promote independence in older adults. Controlled Clinical Trials, 22, 453-479. DOI:10.1016/ S0197-2456(01)00139-8

Karbach, J., Verhaeghen, P. (2014). Making working memory work: A meta-analysis of executive control and working memory training in younger and older adults. Psychological Science, 25, 2027-2037. DOI:10.1177/0956797614548725

Kelly, M., Loughrey, D., Lawlor, B., Robertson, I., Walsh, C., Brennan, S. (2014). The impact of cognitive training and mental stimulation on cognitive and everyday functioning of healthy older adults: A systematic review and meta-analysis. Ageing Research Reviews, 15, 28-43. DOI:10.1016/j.arr.2014.02.004

Kueider, A., Parisi, J., Gross, A., Rebok, G. (2012). Computerized cognitive training with older adults: A systematic review. Plos ONE, 7, e40588. DOI:10.1371/journal.pone.0040588

Laker, D. (1990). Dual dimensionality of training transfer. Human Resource Development Quarterly, 1, 209-223. DOI:10.1002/hrdq.3920010303

Lampit, A., Hallock, H., Valenzuela, M. (2014). Computerized cognitive training in cognitively healthy older adults: A systematic review and meta-analysis of effect modifiers. Plos Medicine, 11, e1001756. DOI:10.1371/journal.pmed.1001756

Lustig, C., Shah, P., Seidler, R., Reuter-Lorenz, P. (2009). Aging, training, and the brain: A review and future directions. Neuropsychology Review, 19, 504-522. DOI:10.1007/s11065-009-9119-9

Mahncke, H., Connor, B., Appelman, J., Ahsanuddin, O., Hardy, J., Wood, R., ... Merzenich, M. M. (2006). Memory enhancement in healthy older adults using a brain plasticity-based training program: A randomized, controlled study. Proceedings of the National Academy of Sciences, 103, 12 523-12 528. DOI:10.1073/pnas.0605194103

Martin, M., Clare, L., Altgassen, A. M., Cameron, M. H., Zehnder, F. (2011). Cognition-based interventions for healthy older people and people with mild cognitive impairment. Cochrane database of systematic reviews, 1, 1-48. DOI:10.1002/14651858.CD006220.pub2

McNab, F., Zeidman, P., Rutledge, R., Smittenaar, P., Brown, H., Adams, R., Dolan, R. (2015). Age-related changes in working memory and the ability to ignore distraction. Proceedings of the National Academy of Sciences, 112, 6515-6518. DOI:10.1073/pnas.1504162112

Metcalfe, J. (red.). (1998). The brain - degeneration, damage and disorder. Heidelberg: Springer. 
Morrison, A., Chein, J. (2011). Does working memory training work? The promise and challenges of enhancing cognition by training working memory. Psychonomic Bulletin \& Review, 18, 46-60. DOI:10.3758/s13423-010-0034-0

Mowszowski, L., Lampit, A., Walton, C., Naismith, S. (2016). Strategy-based cognitive training for improving executive functions in older adults: A systematic review. Neuropsychology Review, 26, 252-270. DOI:10.1007/s11065-016-9329-x

Mozolic, J. (2010). A cognitive training intervention increases resting cerebral blood flow in healthy older adults. Frontiers in Human Neuroscience, 4, 16. DOI:10.3389/neuro.09.016.2010

Nyberg, L., Lövdén, M., Riklund, K., Lindenberger, U., Bäckman, L. (2012). Memory aging and brain maintenance. Trends in Cognitive Sciences, 16, 292-305. DOI:10.1016/j.tics.2012.04.005

O’Connor, M., Hudak, E., Edwards, J. (2011). Cognitive speed of processing training can promote community mobility among older adults: A brief review. Journal of Aging Research, 2011, 1-4. DOI:10.4061/2011/430802

Owen, A., Hampshire, A., Grahn, J., Stenton, R., Dajani, S., Burns, A., ... Ballard, C. G. (2010). Putting brain training to the test. Nature, 465, 775-778. DOI:10.1038/nature09042

Papp, K., Walsh, S., Snyder, P. (2009). Immediate and delayed effects of cognitive interventions in healthy elderly: A review of current literature and future directions. Alzheimer's \& Dementia, 5, 50-60. DOI:10.1016/j.jalz.2008.10.008

Park, D., Festini, S. (2016). Theories of memory and aging: A look at the past and a glimpse of the future. The Journals of Gerontology. Series B: Psychological Sciences and Social Sciences, 72, 82-90. DOI:10.1093/geronb/gbw066

Park, D., Lautenschlager, G., Hedden, T., Davidson, N., Smith, A., Smith, P. (2002). Models of visuospatial and verbal memory across the adult life span. Psychology and Aging, 17, 299-320. DOI:10.1037/0882-7974.17.2.299

Perfect, T., Maylor, E. (2000). Models of cognitive aging. Oxford: Oxford University Press.

Quigley, C., Muller, M. (2014). Feature-selective attention in healthy old age: A selective decline in selective attention? Journal of Neuroscience, 34, 2471-2476. DOI:10.1523/JNEUROSCI.2718-13.2014

Rebok, G., Ball, K., Guey, L., Jones, R., Kim, H., King, J., ... Willis, S. (2014). Ten-year effects of the advanced cognitive training for independent and vital elderly cognitive training trial on cognition and everyday functioning in older adults. Journal of the American Geriatrics Society, 62, 16-24. DOI:10.1111/ jgs. 12607

Rebok, G., Carlson, M., Langbaum, J. (2007). Training and maintaining memory abilities in healthy older adults: Traditional and novel approaches. Journals of Gerontology. Series B: Psychological Sciences and Social Sciences, 62(1), 53-61. 
Reijnders, J., van Heugten, C., van Boxtel, M. (2013). Cognitive interventions in healthy older adults and people with mild cognitive impairment: A systematic review. Ageing Research Reviews, 12, 263-275. DOI:10.1016/j.arr.2012.07.003

Rocznik Statystyczny Rzeczypospolitej Polskiej. (2014). Warszawa: GUS.

Royall, D., Chiodo, L., Polk, M. (2003). Executive dyscontrol in normal aging: Normative data, factor structure, and clinical correlates. Current Neurology and Neuroscience Reports, 3, 487-493. DOI:10.1007/s11910-003-0052-7

Saczynski, J. S., Margrett, J. A., Willis, S. L. (2004). Older adults' strategic behavior: Effects of individual versus collaborative cognitive training. Educational Gerontology, 30, 587-610. DOI:10.1080/03601270490466985

Salthouse, T. (2006). Mental exercise and mental aging. Evaluating the validity of the "use it or lose it" hypothesis. Perspectives on Psychological Science, 1, 68-87. DOI:10.1111/j.1745-6916.2006.00005.x

Schmiedek, F., Lövdén, M., Lindenberger, U. (2010). Hundred days of cognitive training enhance broad cognitive abilities in adulthood: Findings from the COGITO Study. Frontiers in Aging Neuroscience, 2, 27. DOI:10.3389/ fnagi.2010.00027

Stuss, D., Robertson, I., Craik, F., Levine, B., Alexander, M., Black, S., ... Wincour, G. (2007). Cognitive rehabilitation in the elderly: A randomized trial to evaluate a new protocol. Journal of the International Neuropsychological Society, 13, 120-131. DOI:10.1017/s1355617707070154

Tardif, S., Simard, M. (2011). Cognitive stimulation programs in healthy elderly: A review. International Journal of Alzheimer's Disease, 2011, 1-13. DOI:10.4061/2011/378934

Tennstedt, S. L., Unverzagt, F. W. (2013). The ACTIVE Study: Study overview and major findings. Journal of Aging and Health, 25(Suppl. 8), 3-20. DOI:10.1177/0898264313518133

Verhaeghen, P., Marcoen, A., Goossens, L. (1992). Improving memory performance in the aged through mnemonic training: A meta-analytic study. Psychology and Aging, 7(2), 242-251. DOI:10.1037/0882-7974.7.2.242

Willis, S., Tennstedt, S., Marsiske, M., Ball, K., Elias, J, Koepke, K., ... Wright, E. (2006). Long-term effects of cognitive training on everyday functional outcomes in older adults. JAMA: The Journal of the American Medical Association, 296, 2805-2814. DOI:10.1001/jama.296.23.2805

West, R., Bagwell, D., Dark-Freudeman, A. (2008). Self-efficacy and memory aging: The impact of a memory intervention based on self-efficacy. Aging, Neuropsychology, and Cognition, 15, 302-329. DOI:10.1080/13825580701440510

West, R., Bowry, R. (2005). Effects of aging and working memory demands on prospective memory. Psychophysiology, 42, 698-712. DOI:10.1111/j.1469-8986.2005.00361.x

Wood, J., Owsley, C. (2016). Vision and driving: a look at the research road ahead. Clinical and Experimental Optometry, 99, 393-394. DOI:10.1111/cxo.12450 
Zec, R. (1995). The neuropsychology of aging. Experimental Gerontology, 30, 431-442.

Zelinski, E. (2009). Far transfer in cognitive training of older adults. Restorative Neurology and Neuroscience, 27, 455-471. DOI:10.3233/RNN-2009-0495

Zelinski, E. (2010). Scientific critique of BBC / Nature Brain Training Experiment. SharpBrains. Pobrano z: https://sharpbrains.com/blog/2010/05/10/ scientific-critique-of-bbc-nature-brain-training-experiment/ 